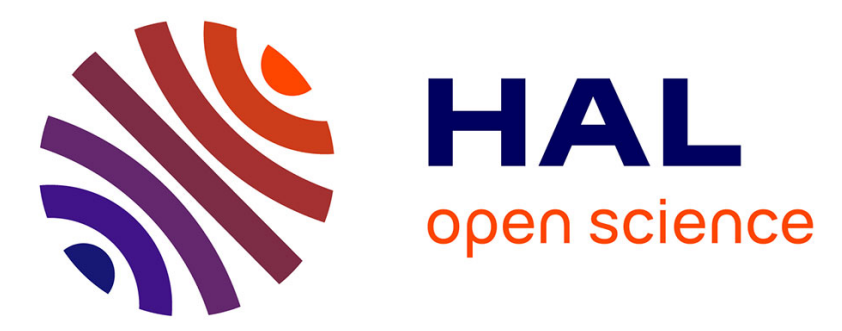

\title{
Aluminum inhibits the growth of hydroxyapatite crystals developed on a biomimetic methacrylic polymer.
}

Cristinel Nicolae Degeratu, Guillaume Mabilleau, Corneliu Cincu, Daniel

Chappard

\section{- To cite this version:}

Cristinel Nicolae Degeratu, Guillaume Mabilleau, Corneliu Cincu, Daniel Chappard. Aluminum inhibits the growth of hydroxyapatite crystals developed on a biomimetic methacrylic polymer.. Journal of Trace Elements in Medicine and Biology, 2013, 27, pp.346-51. 10.1016/j.jtemb.2013.05.004 . hal03265946

\author{
HAL Id: hal-03265946 \\ https://univ-angers.hal.science/hal-03265946
}

Submitted on 21 Jun 2021

HAL is a multi-disciplinary open access archive for the deposit and dissemination of scientific research documents, whether they are published or not. The documents may come from teaching and research institutions in France or abroad, or from public or private research centers.
L'archive ouverte pluridisciplinaire HAL, est destinée au dépôt et à la diffusion de documents scientifiques de niveau recherche, publiés ou non, émanant des établissements d'enseignement et de recherche français ou étrangers, des laboratoires publics ou privés. 


\title{
Aluminum inhibits the growth of hydroxyapatite crystals developed on a biomimetic methacrylic polymer
}

\author{
Cristinel N. Degeratu ${ }^{\mathrm{a}, \mathrm{b}}$, Guillaume Mabilleau ${ }^{\mathrm{b}, \mathrm{c}}$, Corneliu Cincu ${ }^{\mathrm{a}}$, Daniel Chappard ${ }^{\mathrm{b}, \mathrm{c}, *}$

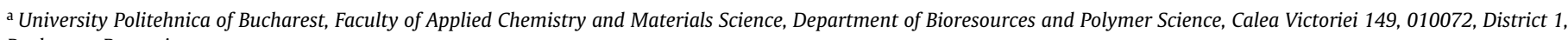 \\ Bucharest, Romania \\ b GEROM - LHEA Groupe Etudes Remodelage Osseux et bioMatériaux, IRIS-IBS Institut de Biologie en Santé, LUNAM Université, CHU d'Angers, 49933 Angers Cedex, France \\ c SCIAM, Service Commun Imageries et Analyses Microscopiques, IRIS-IBS Institut de Biologie en Santé, LUNAM Université, CHU d'Angers, 49933 Angers Cedex, France
}

\section{A R T I C L E I N F O}

\section{Article history:}

Received 18 April 2013

Accepted 21 May 2013

\section{Keywords:}

Aluminum

Mineralization

Hydroxyapatite

Biomimetic polymer

Calcification

\begin{abstract}
A B S T R A C T
Project: Aluminum $(\mathrm{Al})$ is an increasing problem in biomedicine since it can interact with phosphates. Bone is one of the preferential target tissues of Al deposition: Al interacts with mineralization and/or bone cell activities. We searched the influence of $\mathrm{Al}$ deposition in hydroxyapatite developed on a biomimetic polymer (carboxymethylated poly(2-hydroxyethyl-methacrylate)) which mimics bone mineralization in the absence of cells.

Procedures: Pellets of polymer were incubated for 5 days in a synthetic body fluid (SBF) to induce mineralization, then 21 days in SBF containing 20, 40 and $60 \mu \mathrm{g} / \mathrm{L} \mathrm{Al}^{3+}$. Other pellets were incubated in SBF containing commercial Al foil (33 mg/vial) either in 1,2 or 6 pieces. The mineral deposits were dissolved in $\mathrm{HCl}$ and $\mathrm{Ca}^{2+}, \mathrm{PO}_{4}{ }^{3-}$ and $\mathrm{Al}^{3+}$ content was measured. Hydroxyapatite was characterized by SEM and $\mathrm{X}$ energy-dispersive X-ray analysis (EDX).

Results: The amount of $\mathrm{Al}^{3+}$ was dose-dependently increased in $\mathrm{Ca} / \mathrm{P}$ deposits on the polymer pellets. At high concentration (or with the $6 \mathrm{Al}$ foils) growth of hydroxyapatite calcospherite was inhibited; only calcified plates emerging from the polymer were observed. Pellets incubated with 1 and 2 Al foils exhibited a reduction in calcospherite diameter and an increase in the $\mathrm{Al}^{3+} / \mathrm{Ca}^{2+}$ ratio. EDX identified $\mathrm{Al}$ in the mineral deposits.

Conclusions: In this acellular model, $\mathrm{Al}^{3+}$ altered the growth of calcospherites at low concentration and inhibited their development at high concentration. In SBF, a release of $\mathrm{Al}^{3+}$ from aluminum foils also inhibited mineralization. This study emphasizes the importance of $\mathrm{Al}$ in bone pathology and stresses the question of its release from biomaterials.
\end{abstract}

(c) 2013 Elsevier GmbH. All rights reserved.

\section{Introduction}

Aluminum $(\mathrm{Al})$ is the most abundant metal in the terrestrial crust. It is always found combined with other elements such as oxygen, silicon, and fluorine. Aluminum compounds have many different uses, from water-treatment to abrasives and furnace linings. They are also found in consumer products such as antacids, astringents, buffered aspirin, food additives, cosmetics, antiperspirants and medical devices [1].

Although aluminum is commonly encountered in the day-today life, little is known about its biological roles [2]. Al can enter the body through ingestion from water or food consumption, especially

\footnotetext{
* Corresponding author at: GEROM - LHEA Groupe Etudes Remodelage Osseux et bioMatériaux, IRIS-IBS Institut de Biologie en Santé, LUNAM Université, CHU d'Angers, 49933 Angers Cedex, France. Tel.: +33 2446883 49; fax: +3324468 8350 .

E-mail address: daniel.chappard@univ-angers.fr (D. Chappard).
}

processed food with food preservatives and/or colorants containing $\mathrm{Al}$ [3]. Sodium-Al phosphates are considered as safe emulsifying salts in food industry [4]. Al hydroxide is commonly used to stabilize vaccines and, when injected, can create macrophage myofaciitis [5]. Estimates of $\mathrm{Al}$ intakes range from $0.7 \mathrm{mg} /$ day for infants and can reach up to $8-9 \mathrm{mg} /$ day for adults [6]. Al can also be in contact with biological tissues and ions can be released by corrosion from medical implants (e.g. hips prosthesis or dental implants made with the TA6V alloy). Al has been suspected to contribute to the appearance or development of various disorders of the nervous system, as well as of the bone and muscles in humans $[2,7,8]$, namely dementia, anemia, myopathy, bone and joint disease [5,9-11].

Studies have confirmed that $\mathrm{Al}$ is absorbed through the gastrointestinal tract in healthy subjects. However, Al is not an essential trace element in the body [12] and is removed from the body after accumulation in cells of the distal kidney tubule and their desquamation in urine. When kidney functions are altered (renal insufficiency) or when intestinal absorption is increased (e.g. increased intestinal permeability [13]), Al can accumulate in two 
preferential organs: brain (linked to the phosphoproteins, lipids or phosphate groups of DNA [14]) and bone (linked to the phosphate groups of hydroxyapatite, the major $\mathrm{Ca} / \mathrm{P}$ salt of the bone matrix) [15]. Several decades ago, aluminum encephalopathy associated with osteomalacia have been recognized as the major complications of chronic renal failure in dialyzed patients caused by the contamination of the dialysate by $\mathrm{Al}$ and the use of Al-containing phosphate binders $[16,17]$. When $\mathrm{Al}$ has been completely removed from the dialysate and the use of Al-based phosphate binders reduced, the disease has considerably declined.

Al can accumulate in bones at the mineralization front, it inhibits mineralization (leading to osteomalacia) and inhibit osteoblast activity [18-20]. However, the respective role (or entanglement of these factors) is still a matter of debate since it has been suggested that $\mathrm{Al}$ deposition in ostomalacic bone could be a secondary phenomenon that has no influence on mineralization [21].

In this study, we have investigated the role of aluminum on the in vitro growth of synthetic hydroxyapatite crystals. We used a modified polymer, carboxymethylated poly(2-hydroxyethyl methacrylate) (pHEMA-CM), which mimics the calcification of woven bone in the complete absence of cells [22]. Pellets of the polymer were incubated in a synthetic body fluid containing either aluminum ion $\left(\mathrm{Al}^{3+}\right)$ at varying concentrations or with pieces of commercial Al foils. The hydroxyapatite growth in the presence of Al was assessed by chemical analysis, scanning electron microscopy and energy dispersive X-ray analysis.

\section{Materials and methods}

\section{The monomer}

Commercial 2-hydroxyethyl methacrylate (HEMA) was purchased from Sigma-Aldrich Chemical (Illkirsh, France). It is known that, due to the fabrication process, the monomer contains residual methacrylic acid, and ethyleneglycol dimethacrylate. The polymerization inhibitor, 4-methoxyphenol (added at a concentration of $350 \mathrm{ppm}$ by the manufacturer) needed also to be removed. HEMA was purified and distilled under low pressure as previously described [22]. Others chemicals were purchased from Sigma-Aldrich Chemical and used without any purification.

\section{Preparation of polymer pellets}

The polymer was prepared by bulk polymerization as described elsewhere [22]. Polymerization was carried out at $65^{\circ} \mathrm{C}$ for $24 \mathrm{~h}$ in polypropylene wells (Delta Microscopies, Labege, France). In this way, calibrated pellets of pHEMA $(140 \pm 5 \mathrm{mg})$ were obtained with a good reproducibility. Carboxymethylation of the pellets was done as follows: briefly, pellets were washed with deionized water for $30 \mathrm{~min}$ and soaked in $0.5 \mathrm{M}$ bromoacetic acid in a $2 \mathrm{M} \mathrm{NaOH}$ solution overnight at room temperature, under gentle agitation. Pellets of the carboxymethylated polymer (pHEMA-CM) were washed five times (10 min each) in deionized water and dried in an oven at $60^{\circ} \mathrm{C}$ until use.

\section{Incubation of pellets in synthetic body fluids}

A standard synthetic body fluid (SBF $1.5 \times$ ) mimicking the lymph fluid was prepared by dissolving the corresponding quantities of salts $\mathrm{NaCl}, \mathrm{NaHCO}_{3}, \mathrm{KCl}, \mathrm{K}_{2} \mathrm{HPO}_{4}, \mathrm{MgCl}_{2}\left(6 \mathrm{H}_{2} \mathrm{O}\right), \mathrm{CaCl}_{2}\left(2 \mathrm{H}_{2} \mathrm{O}\right)$, $\mathrm{Na}_{2} \mathrm{SO}_{4}$ into demineralised water at $37^{\circ} \mathrm{C}$ accord to Yamada et al. [23]. The $\mathrm{pH}$ of this body fluid was $\mathrm{pH} 7.4$, and it was achieved by using a buffer solution of tris(hydroxymethyl) aminomethane (TRIS) and hydrochloric acid $(\mathrm{HCl})$. The composition (verified on a Technicon SMA analyzer) was as follows: Na: $213.28 \mathrm{mM}$; Ca: $3.73 \mathrm{mM}$; $\mathrm{Mg}$ : $2.25 \mathrm{mM}$; $\mathrm{HCO}_{3}$ : $6.3 \mathrm{mM}$; $\mathrm{Cl}: 212.31 \mathrm{mM}$; $\mathrm{HPO}_{4}$ :
$1.35 \mathrm{mM}$; $\mathrm{SO}_{4}$ : $0.75 \mathrm{mM}$; K: $4.85 \mathrm{mM}$. Pellets of pHEMA-CM were immersed in capped Falcon tubes filled with SBF $1.5 \times$. Pellets were let to soak in a humidified oven at $37{ }^{\circ} \mathrm{C}$, with $5 \% \mathrm{CO}_{2}$ for five days to allow the formation of hydroxyapatite globules at their surface. Then, pellets were randomly allocated in one of the following groups: (i) pellets incubated with SBF served as controls; (ii) pellets incubated with SBF enriched with $20 \mu \mathrm{g} / \mathrm{L} \mathrm{Al}^{3+}$; (iii) pellets immersed in SBF enriched with $40 \mu \mathrm{g} / \mathrm{L} \mathrm{Al}^{3+}$; (iv) pellets incubated with $60 \mu \mathrm{g} / \mathrm{L} \mathrm{Al}^{3+}$. The $\mathrm{Al}^{3+}$ ions were provided by dissolving $\mathrm{AlCl}_{3}$ in the SBF (Sigma-Aldrich). Three additional groups of pellets were incubated with freshly cut pieces of commercial Al foil (food grade, $16 \mu \mathrm{m}$ in thickness): (v) pellets immersed in SBF containing one piece of $60 \mathrm{~mm} \times 20 \mathrm{~mm} \mathrm{Al} \mathrm{foil} \mathrm{(total} \mathrm{mass:}$ $33 \pm 5 \mathrm{mg}$ ); (vi) pellets incubated in SBF containing two pieces of $30 \mathrm{~mm} \times 20 \mathrm{~mm} \mathrm{Al}$ foil and (vii) pellets incubated in SBF containing six pieces of $20 \mathrm{~mm} \times 10 \mathrm{~mm}$ aluminum foil. Between these three groups, the overall surface and mass of Al foil was maintain constant, only the number of pieces and as such the exposed cutting surface changed. Pellets were incubated for a 21 day-period at $37^{\circ} \mathrm{C}$ in a humidified oven with an inflowing air containing $5 \% \mathrm{CO}_{2}$. The medium was replaced every two days. At the end of the incubation period, pellets were rinsed in deionized water 3 times for $10 \mathrm{~min}$ to remove any non-crystallized ions. Eighty-four pellets were used for the entire study and twelve pellets were allocated in each group. The following analyses were conducted in triplicate.

\section{Chemical analysis}

Pellets were transferred into $1 \mathrm{~mL}$ of $0.2 \mathrm{M} \mathrm{HCl}$ for $24 \mathrm{~h}$ to allow complete dissolution of the mineral deposits. The fluid was then collected and used to determine the amount of free ions on an automated Hitachi 917 spectrophotometer (Roche, France) with standardized clinical reagents for calcium (Calcium Infinity TM Arsenazo III) and phosphate (the reduced phosphomolybdate method) obtained from the manufacturer. Al concentration was determined by Inductively Coupled Plasma Atomic Emission Spectrometry, ICP-AES (Jobin-Yvon JY-238 Ultrace, HORIBA Jobin-Yvon, Longjumeau, France). Measurements were performed on the fluid obtained from three disks incubated in the same conditions, and the mean \pm SD of the triplicate was considered.

\section{Scanning electron microscopy (SEM) and energy-dispersive X-ray} analysis (EDX)

Pellets to be examined by SEM were processed as previously described [24]. Briefly, they were dehydrated and carbon-coated with a MED 020 device (Bal-Tec, Balzers, Liechtenstein). SEM was performed on an EVO LS10 (Carl Zeiss, Nanterre, France) microscope equipped with an energy-dispersive X-ray microanalysis machine (INCA XMAX, Oxford Instruments, Oxford, UK). In order to determine the composition of the mineral deposits, EDX was performed by point analysis. The methods explore several micrometers in thickness [25]. Based on SEM photographs, a number of 50 mineral deposits were measured for each group; the size of the $\mathrm{Ca} / \mathrm{P}$ deposits was done using the ImageJ freeware (NIH, Bethesda, $\mathrm{MD})$.

\section{Statistical analysis}

Statistical analysis was done with Systat statistical software, release 13 (Systat, San José, CA). All results are expressed as mean \pm standard deviation (SD). The Kruskal-Wallis nonparametric ANOVA was used to compare the differences between the groups. Results were considered significant when $p<0.05$. When the ANOVA result was significant, comparison between groups was obtained by the Conover-Inman post hoc test. 
Table 1

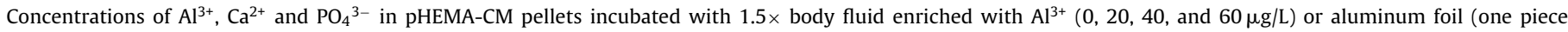
$60 \mathrm{~mm} \times 20 \mathrm{~mm}$; two pieces $30 \mathrm{~mm} \times 20 \mathrm{~mm}$; 6 pieces $20 \mathrm{~mm} \times 10 \mathrm{~mm}$; thickness of $16 \mu \mathrm{m}$ and total mass of $33 \pm 5 \mathrm{mg}$ ).

\begin{tabular}{|c|c|c|c|c|c|}
\hline Source of $\mathrm{Al}^{3+}$ & $\mathrm{Al}^{3+} \mu \mathrm{M} / \mathrm{mg}$ of pHEMA & $\mathrm{Ca}^{2+} \mu \mathrm{M} / \mathrm{mg}$ of $\mathrm{pHEMA}$ & $\mathrm{PO}_{4}{ }^{3-} \mu \mathrm{M} / \mathrm{mg}$ of pHEMA & $\mathrm{Al}^{3+} / \mathrm{Ca}^{2+}$ & $\mathrm{Ca}^{2+} / \mathrm{PO}_{4}{ }^{3-}$ \\
\hline (i) - & $0.020 \pm 0.003$ & $86.1 \pm 0.3$ & $52.0 \pm 0.2$ & $<0.001$ & $1.66 \pm 0.013$ \\
\hline (ii) $20 \mu \mathrm{g} / \mathrm{L}$ & $0.155 \pm 0.007^{*}$ & $86.2 \pm 20.1$ & $52.5 \pm 12.0$ & $<0.001$ & $1.64 \pm 0.008$ \\
\hline (iii) $40 \mu \mathrm{g} / \mathrm{L}$ & $0.245 \pm 0.046^{*}$ & $49.8 \pm 18.0^{*}$ & $31.5 \pm 10.1^{*}$ & $0.006 \pm 0.001^{*}$ & $1.58 \pm 0.030^{*}$ \\
\hline (iv) $60 \mu \mathrm{g} / \mathrm{L}$ & $0.679 \pm 0.261^{*}$ & $6.0 \pm 1.6^{*}$ & $3.9 \pm 1.2^{*}$ & $0.013 \pm 0.011^{*}$ & $1.53 \pm 0.036^{*}$ \\
\hline (v) Al foil $60 \mathrm{~mm} \times 20 \mathrm{~mm}$ & $0.052 \pm 0.007^{*}$ & $29.3 \pm 11.6^{*}$ & $19.6 \pm 8.0^{*}$ & $0.001 \pm 0.000^{*}$ & $1.49 \pm 0.018^{*}$ \\
\hline (vi) Al foil $30 \mathrm{~mm} \times 20 \mathrm{~mm}$ & $0.043 \pm 0.003^{*}$ & $18.9 \pm 12.1^{*}$ & $12.6 \pm 2.5^{*}$ & $0.007 \pm 0.008^{*}$ & $1.51 \pm 0.045^{*}$ \\
\hline (vii) Al foil $20 \mathrm{~mm} \times 10 \mathrm{~mm}$ & $0.042 \pm 0.007^{*}$ & $8.0 \pm 4.2^{*}$ & $5.3 \pm 8.8^{*}$ & $0.013 \pm 0.002^{*}$ & $1.50 \pm 0.039^{*}$ \\
\hline
\end{tabular}

${ }^{*} p<0.05$ vs. untreated.

\section{Results}

\section{Chemical analysis}

Pellets did not vary in shape or weight under standardized polymerization conditions.

They were translucent and their mean weight was $190 \mathrm{mg} \pm 5 \%$, without significant differences between groups. When incubated in SBF enriched with $\mathrm{Al}$ ions, there were significant differences between $\mathrm{Al}$ ion groups and controls for chemical analysis (Table 1 and Fig. 1). As expected, the amount of $\mathrm{Al}^{3+}$ was dose-dependently increased as compared with untreated controls $(p<0.0001)$. On the other hand, the amount of calcium and phosphorus were significantly reduced as the dose of aluminum increased. As a consequence, the $\mathrm{Al} / \mathrm{Ca}$ ratio was markedly increased in a dosedependent manner. The $\mathrm{Ca} / \mathrm{P}$ ratio tended to decrease, however it did not reached significance when compared with untreated controls (Kruskal-Wallis ANOVA: 10.476, $p=0.106$ ).

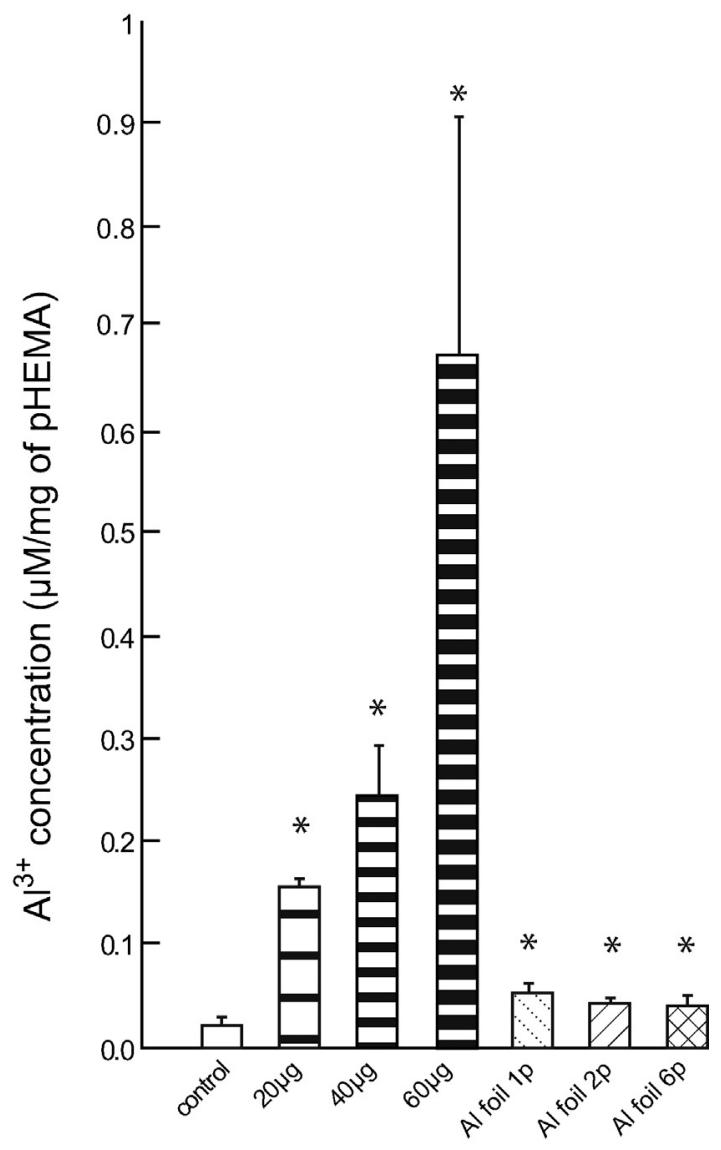

Fig. 1. Amount of $\mathrm{Al}^{3+}$ ion in the mineral deposits deposited at the surface of pHEMA$\mathrm{CM}$ pellets and dissolved in $\mathrm{HCl}$. *: significantly different from the untreated group.
The presence of Al foil pieces in the SBF also dramatically affected the chemical composition of the mineral. Indeed, a marked augmentation in aluminum concentrations and $\mathrm{Al} / \mathrm{Ca}$ ratio were observed in all groups. Furthermore, the $\mathrm{Ca}^{2+}$ and $\mathrm{PO}_{4}{ }^{3-}$ content were dose-dependently reduced in these conditions as well as the $\mathrm{Ca} / \mathrm{P}$ ratio.

\section{Scanning electron microscopy}

After incubation in SBF, a white layer composed of mineralized nodules was clearly seen at the surface of the pHEMA-CM pellets by SEM (Fig. 2a). Mineralized nodules had a round shape (calcospherites) made of elementary tablets or plates of hydroxyapatite, packed together with a mean diameter of $8.19 \pm 0.14 \mu \mathrm{m}$ (Fig. $2 \mathrm{H}$ ). Significant differences were observed in the diameter and shape of mineral deposits between untreated and $\mathrm{Al}$ ions-treated pellets. Indeed, although a white deposit composed of calcium and phosphorus was evidenced at the surface of pHEMA disks incubated with aluminum ions, it was not composed of typical calcospherite but rather appeared as mineralized plates emerging from the polymer surface. This aspect corresponds to the nucleation areas of hydroxyapatite during the first incubation period followed by a complete arrest during the second incubation time. As such, no measurement was made possible.

Al foils were composed of pure aluminum without contaminant (Fig. 1C). Polymer disks immersed in SBF enriched with Al foil pieces also presented with a mineralized layer at their surface. With one and two pieces of aluminum foil, some calcospherites were observed at the surface of the polymer disks but with a significant reduction in their diameters as compared with controls $(4.43 \pm 0.07 \mu \mathrm{m}$ and $3.26 \pm 0.1 \mu \mathrm{m}$ respectively, $p<0.001$ and $p<0.001$ respectively Fig. $2 \mathrm{H}$ ). However, polymer disks incubated in $\mathrm{SBF}$ in the presence of six aluminum pieces presented with platelike mineral deposits similar to those observed with the aluminum ion concentrations.

Energy dispersive X-ray analysis reveals the presence of aluminum only at the highest concentration in aluminum ion groups and on disks incubated with six pieces of aluminum foil (Fig. 3).

\section{Discussion}

Hydroxyapatite is a critical component of the bone matrix as any alteration of the mineral lead to dramatic alteration of quality of the bone matrix and hence resistance to fracture [26]. Mineral growth on pHEMA-CM is a non-cellular model mimicking the mineralization of woven bone observed in the growing skeleton, fracture callus, and metaplasia $[22,27,28]$. In this system, we have repeatedly shown that mineralization is independent of any cellular machinery or protein. This system has been developed to test drug efficacy (bisphosphonates), cell adherence, and protein interaction during bone crystal growth $[22,29,30]$. In vitro, we have previously documented abnormal hydroxyapatite organization with several metals known to influence mineralization: 


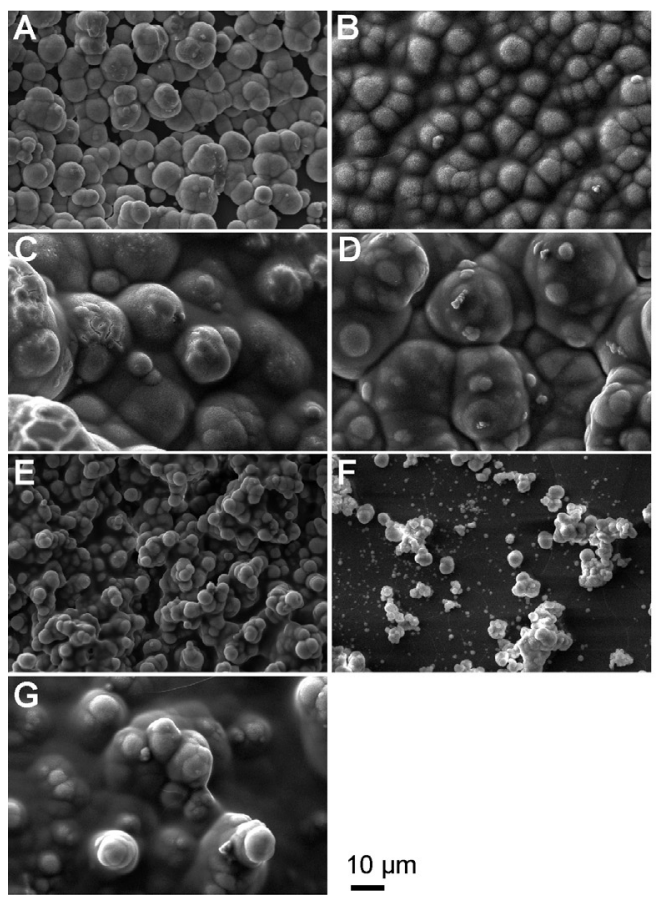

H

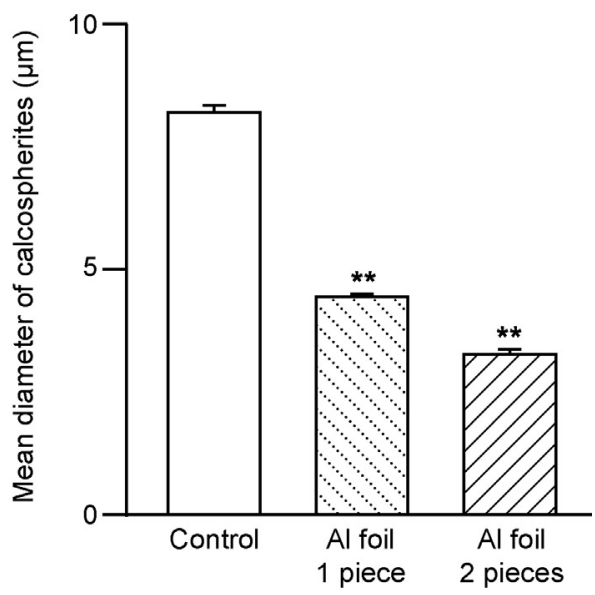

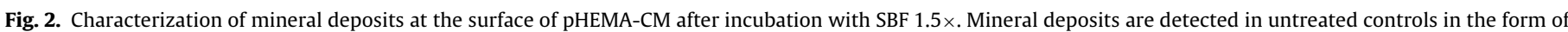

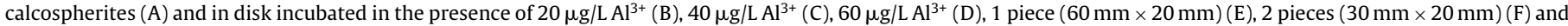

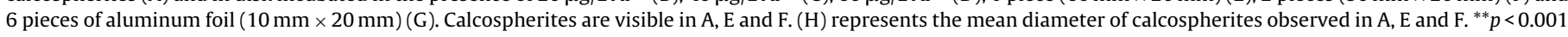
vs. untreated.

strontium [31], iron [32], cobalt, chromium and nickel [33]. In this study, $\mathrm{AlCl}_{3}$ was added in a TRIS- $\mathrm{HCl}$ buffered solution at $\mathrm{pH} 7.4$ and the majority of $\mathrm{Al}$ ions are complexed with hydroxyphosphate/phosphates [34]. First of all, it appeared that Al ions mediated a significant inhibition of mineral deposit at the surface of pHEMA-CM disks dose-dependently. Furthermore, as $\mathrm{Al}^{3+}$ reduces mineralization, we derived the $\mathrm{Al}^{3+} / \mathrm{Ca}^{2+}$ index to assess the incorporation of $\mathrm{Al}^{3+}$ in the mineral composition. The augmentation of $\mathrm{Al}$ ions in $\mathrm{SBF}$ resulted in an increased $\mathrm{Al}$ incorporation into the mineral and thus led to structural modifications of the mineral deposits that did no longer appear with a calcospherite shape but rather with mineral plates emerging from the polymer surface. Because of such an intense inhibition of mineralization, it was not possible to evaluate the Al containing mineral with other methods such as X-ray diffraction or X-ray fluorescence spectrometry.

To simulate the in vivo release of $\mathrm{Al}$ ion from implanted biomaterials containing aluminum, we incubated pieces of freshly cut Al foils. This represented an easy way to bring large amount of $\mathrm{Al}$ ions from a material in a limited incubation period. In regenerative biomedicine, the use of TA6V (a titanium alloy containing $6 \%$ aluminum and $4 \%$ vanadium) is common to prepare orthopedic prosthesis or some types of dental implants [35]. The release of Al from TA6V has been documented in vivo in the microenvironment of baboons which had a segmental bone replacement with TA6V devices [36]. However, because the reduce amount of $\mathrm{Al}$ in this alloy, it would have necessitate a considerable incubation time to evaluate this effect by using pieces of TA6V. In addition, Ti can be released from TA6V and is also known to have deleterious effects [37]. Al release from biomaterials containing high amounts of $\mathrm{Al}$ have been presented: cases of $\mathrm{Al}$ encephalopathy have been well documented with an Al-containing cement [38] and prostheses coated with Al plasma-spray impair mineralization at their contact [39]. Extracellular fluids coming in contact with metallic biomaterials contain many anions $\left(\mathrm{Cl}^{-}, \mathrm{PO}_{4}{ }^{3-}, \mathrm{HCO}_{3}{ }^{-}, \mathrm{SO}_{4}{ }^{2-}\right)$, cations $\left(\mathrm{Na}^{+}, \mathrm{Ca}^{2+}, \mathrm{Mg}^{2+}\right)$, dissolved oxygen, free radicals, proteins, ... and represent a highly corrosive environment which has a $\mathrm{Cl}^{-}$ concentration equivalent to $1 / 3$ of that of seawater and an oxygen concentration equal to $1 / 4$ that of the air [40]. The body temperature also increases the capacity of these corrosive liquids. In addition, the SBF composition ( $\mathrm{pH}$, buffering, ... ) frequently undergoes local fluctuations [41]. The high amounts of phosphates are very corrosive for $\mathrm{Al}$ which has a marked affinity for the $\mathrm{PO}_{4}{ }^{3-}$ ions [42]. Incubation of polymer disks with aluminum foils in SBF resulted in surface oxidation leading to a mineralization inhibition and $\mathrm{Al}$ incorporation into the mineral deposit. Noteworthy is the presence of calcospherites observed at the surface of polymer disk with one or two piece of aluminum foils. Nevertheless, incorporation of $\mathrm{Al}^{3+}$ into the mineral lattice led to dramatic alterations in calcospherites size. As the possible exposed area of aluminum increased, inhibition of mineralization and mineral alterations occurred with aluminum foils.

A study in the early 80s which was conducted on 21 patients which were selected based on radiologic osteomalacia and/or suspicion of aluminum intoxication and skeletal lesions of osteitis fibrosa [28] strongly suggested that aluminum can interfere with normal mineralization. In the patient group of osteomalacic uremic bone tissue who have been exposed to aluminum-containing dialysis fluid, the preferentially localization of aluminum was at the junction of mineralized bone and osteoid tissue, where the bone mineral is normally first deposited. In rats receiving drinking water enriched with $\mathrm{Al}$ chloride, a decrease in the bone mineral density was observed after 150 days but no histological control of the mineralization degree was available [43]. In this study, aluminum was passively incorporated in hydroxyapatite and interfered with crystal size growth independently of any cellular, hormonal, or protein intervention. In our study, scanning electron microscopy showed a direct effect of aluminum on the crystal growth, a finding previously described by crystal modeling [44] and in synthetic hydroxyapatites [45].

The presence of metal elements in bone, such as iron, cobalt, chromium, nickel, aluminum or lead, especially in humans with 
A

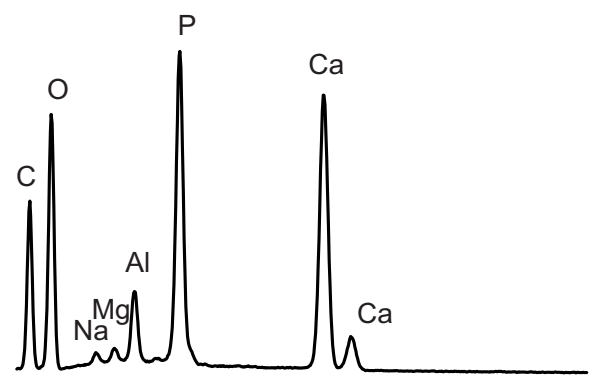

B

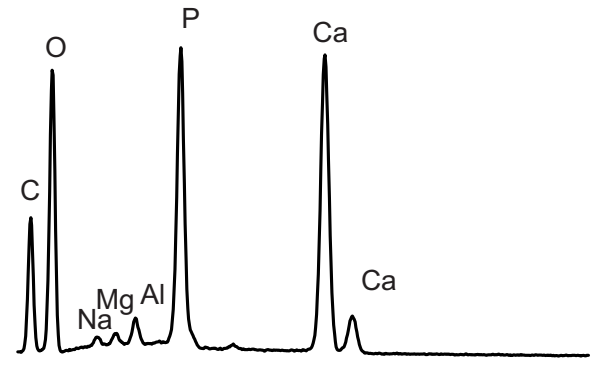

C

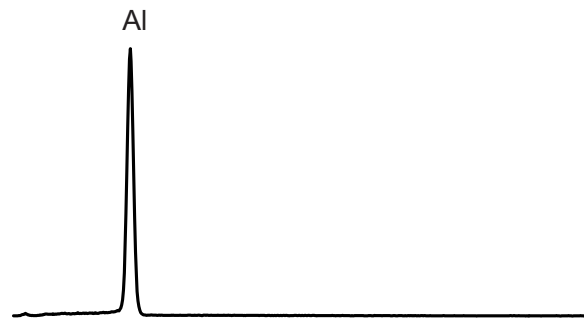

Fig. 3. EXD analysis of polymer disks incubated in the presence of $60 \mu \mathrm{g} / \mathrm{L}$ of $\mathrm{Al}^{3+}$ (A) or 6 pieces of aluminum foil (B). The EDX spectrum of a native $\mathrm{Al}$ foil is provided in (C).

metallic implants, is well documented; however, the precise toxicity mechanisms remain largely unknown. In a human study on the effects of aluminum on bone localization, the range of $\mathrm{Al}^{3+}$ found in bone was between 25 and 130 ppm [28].

One limitation of this study is linked to the acellular system used to assess the direct effect of $\mathrm{Al}^{3+}$ on mineral deposition. Indeed, physiologically, bone mineralization is a complex phenomenon involving a protein pattern, deposited by bone cells that allow clear spaces for mineralization initiation and growth. The effects of aluminum on bone cells and as such protein pattern has not been investigated in the present study and represent additional mechanisms explaining the bone loss associated with $\mathrm{Al}$ ingestion. Recently, Al was found to induce osteoblast apoptosis which can explain the reduction of bone mass in patients with $\mathrm{Al}$ intoxication associated with cessation of the mineralization process [46].

\section{Conclusions}

Al ions significantly inhibited hydroxyapatite growth at the surface of pHEMA-CM and completely modified the morphology of calcospherites, first by decreasing their mean diameter, then by converting them in less structured calcified plates. A very similar observation was reported in the same model with tiludronate, a bisphosphonic compound used as an antiosteoclastic drug. Inhibition of calcification and changing calcospherites into less-structured plates was observed [47]. We also evidenced this severe alteration of the newly formed mineral with incorporation of $\mathrm{Al}$ ions into the mineral lattice by SEM and EDX. Al interfered with mineralization either when provided in the SBF or it can be released from the foils although the metal is passivated by a layer of aluminum oxide.

\section{Conflict of interest}

None disclosed.

\section{Acknowledgments}

This work was made possible by grants from Contrat de Plan Etat - Région "Pays de la Loire" Bioregos2. M. Degeratu was funded by the Sectoral Operational Program Human Resources Development 2007-2013 of the Romanian Ministry of Labor, Family and Social Protection through the Financial Agreement POSDRU/88/1.5/S/61178.

\section{References}

[1] Helmboldt O, Keith HL, Misra C, Wefers K, Heck W, Stark H, et al. Aluminum compounds, inorganic. Ullmann's Encyclopedia of Industrial Chemistry. Weinheim: Wiley-VCH Verlag GmbH \& Co. KGaA; 2000.

[2] Banks WA, Kastin AJ. Aluminum-induced neurotoxicity: alterations in membrane function at the blood-brain barrier. Neurosci Biobehav Rev 1989;13:47-53.

[3] Ferreira PC, Piai Kde A, Takayanagui AM, Segura-Munoz SI. Aluminum as a risk factor for Alzheimer's disease. Rev Lat Am Enfermagem 2008;16:151-7.

[4] Yokel RA, Hicks CL, Florence RL. Aluminum bioavailability from basic sodium aluminum phosphate, an approved food additive emulsifying agent, incorporated in cheese. Food Chem Toxicol 2008;46:2261-6.

[5] Ghérardi R, Coquet M, Cherin P, Belec L, Moretto P, Dreyfus PA, et al. Macrophagic myofasciitis lesions assess long-term persistence of vaccinederived aluminium hydroxide in muscle. Brain 2011;124:1821-31.

[6] Pennington JA, Schoen SA. Estimates of dietary exposure to aluminium. Food Addit Contam 1995;12:119-28.

[7] Nayak P. Aluminum: impacts and disease. Environ Res 2002;89:101-15.

[8] Goodman WG. Bone disease and aluminum: pathogenic considerations. Am J Kidney Dis 1985;6:330-5.

[9] King SW, Savory J, Wills MR. The clinical biochemistry of aluminum. Crit Rev Clin Lab Sci 1981;14:1-20.

[10] Parkinson IS, Ward MK, Kerr DN. Dialysis encephalopathy, bone disease and anaemia: the aluminum intoxication syndrome during regular haemodialysis. J Clin Pathol 1981;34:1285-94.

[11] Pierides AM. Dialysis dementia, osteomalacic fractures and myopathy: a syndrome due to chronic aluminum intoxication. Int J Artif Organs 1978;1:206-8.

[12] Valkovic V. Is aluminum an essential element for life. Orig Life 1980;10:301-5.

[13] Chappard D, Insalaco P, Audran M. Aluminum osteodystrophy and celiac disease. Calcif Tissue Int 2004;74:122-3.

[14] Kawahara M, Kato-Negishi M. Link between aluminum and the pathogenesis of Alzheimer's disease: the integration of the aluminum and amyloid cascade hypotheses. Int J Alzheimers Dis 2011;2011:276393.

[15] Blumenthal NC, Posner AS. In vitro model of aluminum-induced osteomalacia: inhibition of hydroxyapatite formation and growth. Calcif Tissue Int 1984;36:439-41.

[16] Malluche HH, Faugère MC. Aluminum-related bone disease. Blood Purif 1988;6:1-15.

[17] Faugère MC, Arnala IO, Ritz E, Malluche HH. Loss of bone resulting from accumulation of aluminum in bone of patients undergoing dialysis. J Lab Clin Med 1986;107:481-7.

[18] Sedman AB, Alfrey AC, Miller NL, Goodman WG. Tissue and cellular basis for impaired bone formation in aluminum-related osteomalacia in the pig. J Clin Invest 1987;79:86-92.

[19] Goodman WG, Gilligan J, Horst R. Short-term aluminum administration in the rat. Effects on bone formation and relationship to renal osteomalacia. J Clin Invest 1984;73:171-81.

[20] Parisien M, Charhon SA, Arlot M, Mainetti E, Chavassieux P, Chapuy MC, et al Evidence for a toxic effect of aluminum on osteoblasts: a histomorphometric study in hemodialysis patients with aplastic bone disease. J Bone Miner Res 1988;3:259-67.

[21] Quarles DL, Dennis VW, Gitelman HJ, Harrelson JM, Drezner MK. Aluminum deposition at the osteoid-bone interface. An epiphenomenon of the osteomalacic state in vitamin D-deficient dogs. J Clin Invest 1985;75:1441-7.

[22] Filmon R, Grizon F, Baslé MF, Chappard D. Effects of negatively charged groups (carboxymethyl) on the calcification of poly(2-hydroxyethyl methacrylate). Biomaterials 2002;23:3053-9. 
[23] Yamada S, Nakamura T, Kokubo T, Oka M, Yamamuro T. Osteoclastic resorption of apatite formed on apatite- and wollastonite-containing glass-ceramic by a simulated body fluid. J Biomed Mater Res 1994;28:1357-63.

[24] Filmon R, Chappard D, Baslé MF. Scanning and transmission electron microscopy of poly2-hydroxyethyl methacrylate-based biomaterials. J Histotechnol 1997;20:343-6.

[25] Echlin P, Fiori CE, Goldstein J, Joy DC, Newbury DE. Advanced scanning electron microscopy and X-ray microanalysis. New York: Plenum Press; 1986.

[26] Chappard D, Baslé MF, Legrand E, Audran M. New laboratory tools in the assessment of bone quality. Osteoporos Int 2011;22:2225-40.

[27] Filmon R, Baslé MF, Barbier A, Chappard D. Poly(2-hydroxy ethyl methacrylate)alkaline phosphatase:a composite biomaterial allowing in vitro studies of bisphosphonates on the mineralization process. J Biomater Sci Polym Ed 2000;11:849-68.

[28] Cournot-Witmer G, Zingraff J, Plachot JJ, Escaig F, Lefevre R, Boumati P, et al. Aluminum localization in bone from hemodialyzed patients: relationship to matrix mineralization. Kidney Int 1981;20:375-85.

[29] Filmon R, Grizon E, Cincu C, Baslé MF, Audran M, Chappard D. Preparation of a polymer biomaterial (poly(2-hydroxyethyl methacrylate)) with an interconnected macroporosity. An X-ray microtomographic and histomorphometric study. J Bone Miner Res 2002;17. S305-S05.

[30] Chappard D, Filmon R, Cincu C, Baslé MF. Fetuin and osteocalcin influence calcospherite formation in an in vitro acellular model of calcification. Bone 2005;36. S171-S71.

[31] Beuvelot J, Filmon R, Mauras Y, Baslé MF, Chappard D. Adsorption and release of strontium from hydroxyapatite crystals developed in simulated body fluid (SBF) on poly(2-hydroxyethyl) methacrylate substrates. Dig J Nanomater Biostruct 2013;8:207-17.

[32] Guggenbuhl P, Filmon R, Mabilleau G, Baslé MF, Chappard D. Iron inhibits hydroxyapatite crystal growth in vitro. Metabolism 2008;57:903-10.

[33] Mabilleau G, Filmon R, Petrov PK, Baslé MF, Sabokbar A, Chappard D. Cobalt, chromium and nickel affect hydroxyapatite crystal growth in vitro. Acta Biomater 2010;6:1555-60.

[34] Exley C. Elucidating aluminium's exposome. Curr Inorg Chem 2012;2:3-7.

[35] Russe P, Pascaretti-Grizon F, Aguado E, Goyenvale E, Filmon R, Baslé MF, et al. Does milling one-piece titanium dental implants induce osteocyte and osteoclast changes. Morphologie 2011;95:51-9.
[36] Woodman JL, Jacobs JJ, Galante JO, Urban RM. Metal ion release from titaniumbased prosthetic segmental replacements of long bones in baboons: a longterm study. J Orthop Res 1983;1:421-30.

[37] Degasne I, Baslé MF, Demais V, Huré G, Lesourd M, Grolleau B, et al. Effects of roughness, fibronectin and vitronectin on attachment, spreading, and proliferation of human osteoblast-like cells (Saos-2) on titanium surfaces. Calcif Tissue Int 1999;64:499-507.

[38] Hantson P, Mahieu P, Gersdorff M, Sindic C, Lauwerys R. Fatal encephalopathy after otoneurosurgery procedure with an aluminum-containing biomaterial. J Toxicol Clin Toxicol 1995;33:645-8.

[39] Savarino L, Cenni E, Stea S, Donati ME, Paganetto G, Moroni A, et al. X-raydiffraction of newly formed bone close to alumina-coated or hydroxyapatitecoated femoral stem. Biomaterials 1993;14:900-5.

[40] Hanawa T, Kaga M, Itoh Y, Echizenya T, Oguchi H, Ota M. Cytotoxicities of oxides, phosphates and sulphides of metals. Biomaterials 1992;13:20-4.

[41] Tengvall P, Lundstrom I, Sjoqvist L, Elwing H, Bjursten LM. Titanium-hydrogen peroxide interaction: model studies of the influence of the inflammatory response on titanium implants. Biomaterials 1989;10:166-75.

[42] Kiss T, Zatta P, Corain B. Interaction of aluminium(III) with phosphatebinding sites: biological aspects and implications. Coord Chem Rev 1996;149: 329-46.

[43] Li X, Hu C, Zhu Y, Sun H, Li Y, Zhang Z. Effects of aluminum exposure on bone mineral density, mineral, and trace elements in rats. Biol Trace Element Res 2011:143.

[44] Gutowska I, Machoy Z, Machalinski B. The role of bivalent metals in hydroxyapatite structures as revealed by molecular modeling with the HyperChem software. J Biomed Mater Res Part A 2005;75:788-93.

[45] Sutter B, Taylor RE, Hossner LR, Ming DW. Solid state 31phosphorus nuclear magnetic resonance of iron-, manganese-, and copper-containing synthetic hydroxyapatites. Soil Sci Soc Am J 2002;66:455-63.

[46] Li X, Han Y, Guan Y, Zhang L, Bai C, Li Y. Aluminum induces osteoblast apoptosis through the oxidative stress-mediated JNK signaling pathway. Biol Trace Elem Res 2012;150:502-8

[47] Filmon R, Baslé MF, Barbier A, Chappard D. In vitro study of the effect of bisphosphonates on mineralization induced by a composite material: poly2(hydroxyethyl) methacrylate coupled with alkaline phosphatase. Morphologie 2000;84:23-33. 